\title{
Antep Fıstığı (Pistacia vera L.) Üreticilerinin Tarımsal Mücadele Konusundaki Bilgi Düzeylerinin Belirlenmesi: Türkiye, Siirt İli Örneği
}

\author{
Halil DÍLMEN ${ }^{1 *}$, Frrat PALA ${ }^{1}$, Meryem ÖZER DILMEN ${ }^{2}$

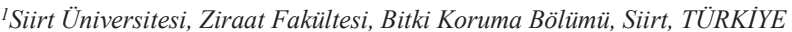 \\ ${ }^{2}$ Siirt Üniversitesi, Eruh Meslek Yüksekokulu, Bitkisel ve Hayvansal Üretim Bölümü, Siirt, TÜRKIYE
}

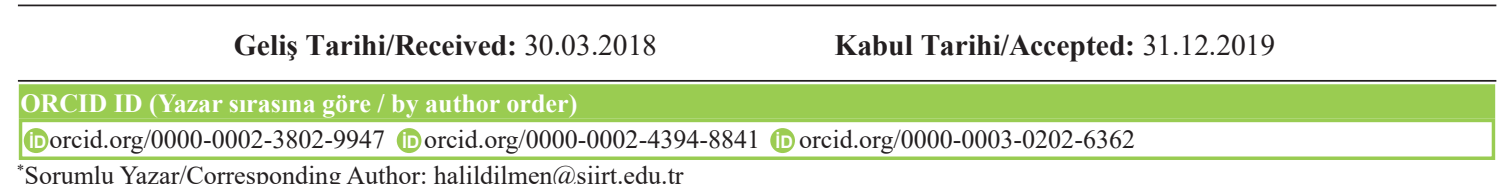

Öz: Bu çalışma; Antep fistığı üreticilerinin tarımsal mücadelede tarım ilacı kullanımı ile ilgili bilgi seviyelerinin belirlenmesi, çevre duyarlılıklarının incelenmesi ve zararlılara karşı en etkili kontrol yöntemlerini önermek amaciyla yürütülmüştür. Çalışma, Türkiye'nin Antep fistığı üretiminde önemli potansiyele sahip olan Siirt ilinde gerçekleștirilmiştir. Çalışmada, \% 95 güven ve $\% 10$ hata düzeyinde tesadüfi yöntemlerle, 100 kişi ile 45 sorudan oluşan bir anket yapılmıştır. Anket sonuçları, istatistiksel analize tabi tutulmuș ve ortalamalar \% olarak değerlendirilmiștir. Elde edilen bulgulara göre; üreticilerin \% 66'sının zararlının yoğunluğuna bakmaksızın tarım ilacı kullandığı, \% 71'inin ilaç dozunu etikete göre hazırlamadığı, \% 83'ünün biyolojik mücadeleyi bilmediği ve \% 88'inin entegre mücadele hakkında herhangi bir bilgiye sahip olmadığ tespit edilmiştir. Çalışma sonucunda, üreticilerin eğitim seviyelerinin düşük olduğu, tarım ilaçlarını aşırı miktarda kullandığı, insan ve çevre sağlığı ile biyoçeşitlilik gibi konuları önemsemedikleri ortaya çıkmıștır. Sonuç olarak, Antep fistığ yetiştiricilerine ilgili kurumlar tarafindan tarımsal mücadele konusunda belirli aralıklarla eğitimlerin düzenlenmesi son derece faydalı olacağı kanısındayız.

Anahtar Kelimeler: Antep fistığı, bitki koruma, tarımsal mücadele, tarım ilacı

\section{Determination of Knowledge Level of Pistachio (Pistacia vera L.) Growers on Agricultural Pest Control: The Case of Province Siirt, Turkey}

\begin{abstract}
This study was carried out in order to determine the knowledge levels of pistachio producers in Siirt province about the use of pesticides in the agricultural pest control, to examine environmental sensitivity and to propose the most effective control methods against pests. The study was performed in Siirt province of Turkey, which has significant potential in pistachio production. In this study, a survey consisting of 45 questions was applied to 100 people by random methods at $95 \%$ confidence level and $10 \%$ error level. The results of the survey were analysed by statistical analysis methods, and the averages were evaluated as percentage. According to the findings, it was found that $71 \%$ of the growers did not prepare the pesticide dose according to the label, $66 \%$ use pesticides regardless of the intensity of the pests, $83 \%$ did not know the biological pest control and $88 \%$ did not have any information about the integrated pest management. As a result of the study, it was found out that producers have low education levels, excessive pesticide use behaviour and they are careless about human, environmental health and biodiversity. In conclusion, we believe that it will be extremely helpful to organize regular trainings for pistachio growers by the relevant institutions on agricultural pest control.
\end{abstract}

Keywords: Pistacia vera, plant protection, agricultural pest control, pesticide 


\section{Giriş}

Antep fistığ 1 (Pistacia vera L.); Türkiye, Amerika Birleşik Devletleri, İran, Çin, Suriye ve Yunanistan başta olmak üzere birçok ülkede yetiştirilmekte, gün geçtikçe tarımı yaygınlaşmaktadır. Türkiye'de Antep fistığı tarımının \% 90’1 Güneydoğu Anadolu Bölgesi'ndeki illerde yapılmakta; üretimin en fazla olduğu iller Gaziantep, Şanlıurfa, Adıyaman, Siirt ve Kahramanmaraş şeklinde sıralanmaktadır (Anonim, 2019).

Antep fistığı (P. vera L.) yetiştiriciliği, çok eski zamanlardan beri Güneydoğu Anadolu Bölgesi'nde yapılmakta; bölge bu bağlamda hem Antep fistığının gen kaynağı olması hem de ilk bu bölgede kültüre alınması noktasında önemlidir. Ayrıca bölgenin kendine özgü çevre koşulları bu bitki türünün başarılı bir biçimde yetişmesini ve hızlı bir şekilde yayılmasını sağlamıştır. Antep fistığı, toprak isteği bakımından çok seçici olmayıp, kurak hava şartlarına da dayanıklıdır. $\mathrm{Bu}$ nedenle, Güneydoğu Anadolu Bölgesi'nin; sulamanın yapılmadığı dağlık, kayalık ve kireçli toprak yapısına sahip engebeli arazilerinde bile tarımı yaygındır. Bunun yanı sıra, anaç olarak kullanılan Menengiç (P. terebinthus L.) ve Buttum (P. khinjuk Stocks.)'un Güneydoğu Anadolu Bölgesi'nde kendiliğinden bulunması, Antep fistığ1 yetiştiriciliğini de daha cazip hale getirmiştir. Antep fistığı tarımı hem Türkiye için önemli bir ekonomik değer hem de yöre çiftçileri için önemli bir gelir kaynağı olmuştur (Anonim, 2015).

Antep fistığı yetiştiriciliğinde özellikle; sulama, toprak işleme, budama, gübreleme, hasat, hastalık ve zararlılarla mücadele gibi kültürel uygulamaların eksiksiz ve uygun zamanlarda yapılması yüksek verimin elde edilmesinde büyük önem taşımaktadır. Antep fıstığ 1 tarımında verimi düşüren birçok zararlı ve hastalıklar bulunmaktadır. Bu kapsamda dünyada ve Türkiye'de şimdiye kadar yapılan birçok çalışmaya rastlanılmaktadır (Mehrnejad, 2003; Rad, 2006; Özgen ve ark., 2015; Kaplan ve ark., 2018; Kaplan, 2019; Aydın, 2019).

Bolu (2002) tarafindan Güneydoğu Anadolu Bölgesi'ndeki illerde yürütülen bir çalışmada, 70 zararlı böcek türünün bulunduğu ve bunlar içerisinde 8 tanesinin ekonomik anlamda önemli verim kayıplarına neden olduğu bildirilmektedir. Söz konusu türler araştırmacı tarafından; Agonoscena pistaciae Burckhardt ve Lauterer, Kermania pistaciella Amsel, Sulamicerus (Idocerunus) stali (Fieb.), Suturaspis pistaciae Lind, Chaetoptelius vestitus M.-R, Pistaciaspis pistaciae Arch., Megastigmus pistaciae Walk. ve Capnodis cariosa Pall. olarak rapor edilmiştir.
Tarımsal üretim sırasında ortaya çıkan zararlı ya da hastalık problemleri, eğer ekonomik zarar seviyesinde kayılara neden oluyorlarsa, o zaman buna karşı gerekli önlemlerin alınmasını da zorunlu hale getirmektedir. Zararlı ve hastalık etmenine göre uygun yöntemler ile tarımsal mücadele (Kültürel, fiziksel, biyolojik, kimyasal, biyoteknolojik ve entegre mücadele) yapilarak verim kayıpları önlenebilmektedir. Tarımsal mücadelede amaç; kültür bitkilerinde zararlı türlerin popülasyon dinamikleri ve çevre ile ilişkilerine bakılarak, uygun olan tüm mücadele yöntem ve tekniklerini birbiriyle uyumlu bir șekilde kullanarak, popülasyon yoğunluklarını ekonomik zarar seviyesinin altında tutmaktır. Bu şekilde entegre mücadele yapıldığında istenilen fayda sağlanabilir. Ancak tarımda bilinçsizce ve yanlış yapılan ilaçlamaların neticesinde; insanların, diğer yaşam formlarına ve çevreye istenmeyen yan etkilerinin potansiyel bir risk oluşturduğuna dair birçok kanıt vardır (Jeyaratnam, 1985; Igbedioh, 1991; Forget, 1993). Özellikle pestisitlerin toprak işleme ile toprağa karışması mikroorganizma popülasyonlarını olumsuz etkilediğini bildirmişlerdir (Aslihan ve ark., 2009). Pestisitler hedef olmayan bitkileri öldürmeye ek olarak subletal etkilere neden olmaktadır. Bazı insektisitler ve fungisitler bitkilere de zarar verebilir (Aktar ve ark., 2009). Ayrıca bazı hastalıklara duyarlılı̆̆ artabilir (Brammall ve Higgins, 1988). Herbisitler tohum kalitesini de ciddi şekilde azaltabilir (Locke ve ark., 1995). Tüm bu olumsuzluklara rağmen, kimyasal mücadele önemini hala korumaktadır. Günümüzde tarımsal üretimin ayrılmaz bir parçası haline gelen tarım ilaçların tarımsal mücadelede kullanımına karar vermeden önce mevcut durumun ortaya konulması şarttır. Bunun için "Entegre mücadele" ilkeleri doğrultusunda sürdürülebilir tarım anlayışıyla ilaçlı tarımsal mücadelenin yapılması; insan, çevre, su, ve toprağa zararını en aza indirmek açısından önemlidir.

$\mathrm{Bu}$ araştırma, Türkiye'de Antep fistığ yetiştiriciliği yapan çiftçilerin tarımsal mücadele yaparken bitki koruma ürünlerine konusunda bilinç düzeyleri ile çevreye karşı hassasiyetlerini, Antep fıstığ 1 tarımında önemli potansiyele sahip Siirt ili özelinde belirlemek ve çiftçilere en etkili kontrol metotlarını önermek amacıyla yapılmıştır.

\section{Materyal ve Yöntem}

Bu çalışmanın materyalini; Türkiye'nin Güneydoğu Anadolu Bölgesi'nde Antep fistığ1 yetiştiriciliğinin yoğun olduğu Siirt ilinde, 2016 yılında, rastgele seçilmiş üreticilerle yapılan anket sorularından oluşan veriler meydana getirmektedir. Araştırma kapsamında, anket çalışması yapılan Antep fistığı 
yetiştirici sayısı oransal örnek hacmi Eşitlik 1 yardımıyla hesaplanmıştır (Newbold, 1995).

$$
n=\frac{N \cdot p(1-p)}{(N-1) \sigma p_{x}{ }^{2}+p(1-p)}
$$

Eşitlikte n, örnek hacmini; N, Antep fistı $\breve{g}_{1}$ yetiştirici sayısını; $\sigma^{2} p_{x}$, oranın varyansını; $p$, Antep fıstığ 1 yetiştiriciliği yapanların oranını (0.50) ifade etmektedir.

Üreticilere karşılıklı sözlü olarak sorulan sorulara verilen cevaplar anket formlarına işlenmiștir. Anket \% 95 güven düzeyinde \% 10 hata ile toplamda 88 kişiye karşılık gelirken; Siirt'teki toplamda 8500 Antep fistığ üreticisi arasından bu say1 Siirt merkezde 20, Tillo'da 20, Eruh'ta 25, Şirvan'da 20 ve Kurtalan'da 15 olmak üzere toplam 100 kişiye tamamlanmıştır. Elde edilen bulgular Microsoft Excel programında yüzde değerleri pasta grafiklerde görüntülenerek, Siirt ilindeki üreticilerin tarımsal zararlılarla savaşım konusundaki bilgileri ve kimyasal savaşım uygulamalarına yaklaşımları belirlenmiştir.

\section{Bulgular ve Tartışma}

$\mathrm{Bu}$ çalışmada; Siirt iline bağlı Merkez, Eruh, Kurtalan, Şirvan ve Tillo ilçelerinde fistık yetiştiriciliği yapan üreticilerin öncelikle eğitim durumu, yaşı, ailede birlikte yaşadıkları birey sayısı, var ise ikinci bir mesleği, yaşadıkları köyün tipi, merkeze uzaklığı gibi genel özellikleri ortaya konulmuş; daha sonra ise çiftçilerin sahip oldukları toplam arazi varlığı, sulanabilen arazi miktarı belirlenmiştir. Ayrıca üreticilerin sahip oldukları arazide yetiştirdikleri ürünler ve önemli verim kayıplarına sebep olan zararlılar gibi veriler elde edilmiştir. En son olarak fistık üreticilerinin tarımsal savaş konusundaki bilgileri ve kimyasal savaşım uygulamaları açısından davranış özellikleri incelenmiştir.

Çalışma verilerine göre, görüşülen üreticilerin \% 5'inin okuryazar olmadığı, \% 56'sının ortaöğretim, \% 26'sının lise, \% 13'ünün üniversite mezunu olduğu tespit edilmiştir (Şekil 1). Çiftçilerin \% 56'sının ilkokul ve ortaokul mezunu olması çeşitli nedenlere bağlı kılınabilir. Ailelerin ekonomik durumlarının iyi olmamasından dolayı genç bireylerin çalışmak için büyük şehirlere göç etmesi, okumanın ailelere büyük yük getirmesi, üniversite mezunlarının ise kamu ile özel sektörde çalışmaları nedeniyle köy yaşamını tercih etmemeleri gibi nedenler üreticilerin eğitim durumlarının düşük olmasına sebep olmuştur. Çiftçilerin genelinin ilkokul mezunu olduğu, üniversite mezunu çiftçilerin sayılarının az olduğu diğer bazı araştırma verilerinde de ifade edilmiştir
(İnan ve Boyraz, 2002; Emeli, 2006; Erdoğan ve Gökdoğan, 2017).

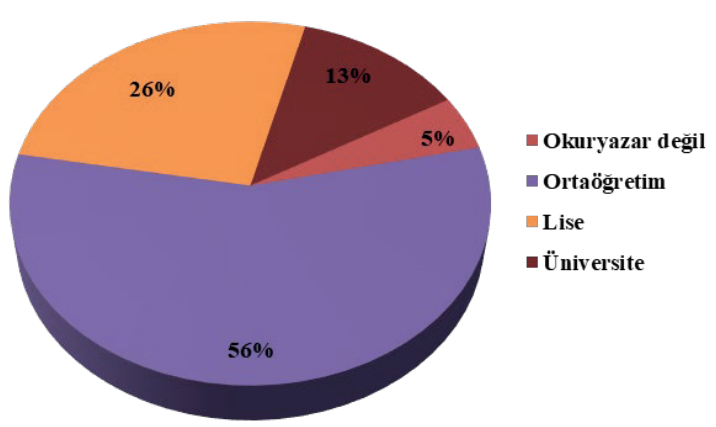

Şekil 1. Çiftçilerin öğrenim düzeyi

Türkiye'de farklı bölgelerde yapılan çalışmalarda üreticilerin öğrenim düzeyleri genelde düşük bulunmuştur. Dolayısıyla hem doğal hayatın korunması hem de çevre bilincinin oluşması, daha karlı bir üretimin yapılması, gereksiz kimyasal ilaç ve gübre kullanımının oluşturduğu zararların farkında olunması ve bu konularda dikkatli davranılması, eğitim durumu ile yakından ilişkilidir. $\mathrm{Bu}$ bağlamda üreticilerin eğitim düzeylerinin yükselmesiyle beraber pek çok sorunun da ortadan kalkacağı öngörülebilir.

Şekil 2'den de görüleceği üzere, çiftçilerin tarımsal üretim yaparken, zirai mücadele konusunda; \% 33 oranında ilaç bayileri, \% 22 oranında Tarım ve Orman il ve ilçe müdürlükleri, $\% 17$ oranında kendi tecrübeleri, \% 10 aile büyükleri, $\% 9$ ziraat mühendisleri $\% 3$ oranında da Ziraat Odaları'ndan gerekli teknik bilgileri aldıklarını bildirmişler; \% 6 oranında ise "teknik destek almıyorum" şeklinde cevap vermişlerdir. İnan ve Boyraz (2002)'ın da çalışmasında ortaya çıktığı üzere, zirai mücadele konusunda çiftçilerin daha çok ilaç bayiliklerinden destek aldıkları görülmüştür.

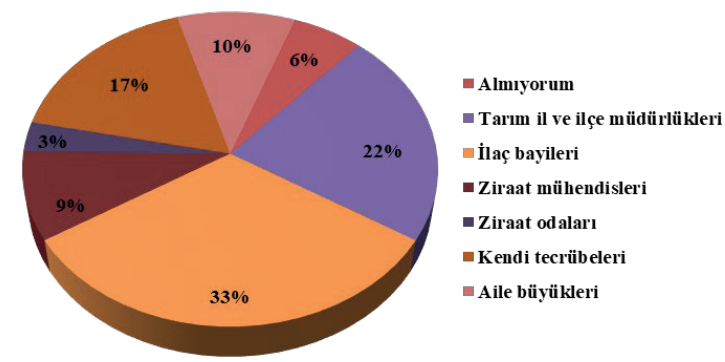

Şekil 2.Tarımsal üretim yaparken muhatap oldukları kurum ve kişiler

Şekil 3 incelendiğinde; ankete katılan üreticilere "en çok hangi amaçla kimyasal ilaçlama yapıyorsunuz” sorusuna \% 60'1 böcekler, \% 19’u 


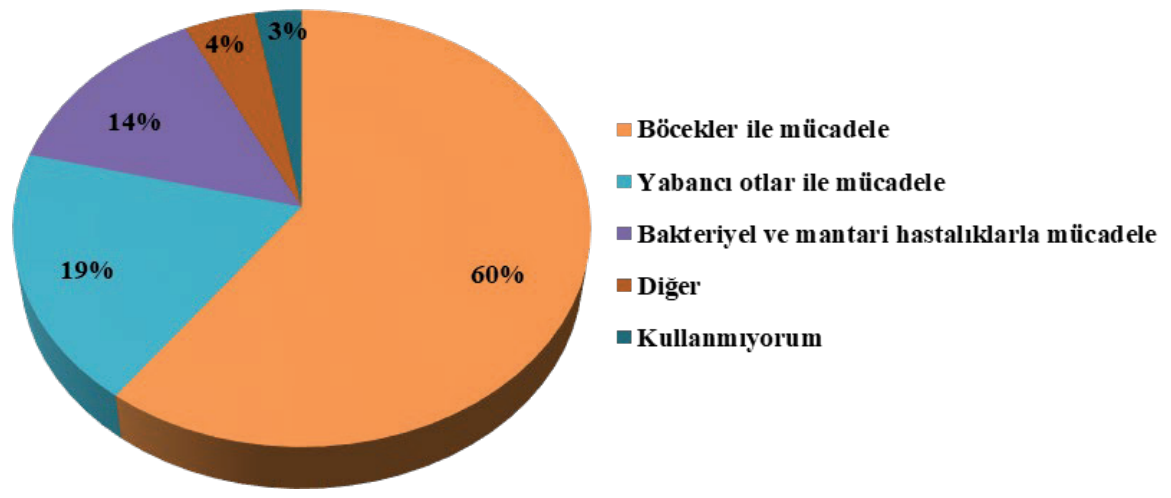

Şekil 3. Çiftçilerin en çok hangi amaçla tarım ilacı kullandıkları

yabancı ot, \% 14'ü bakteriyel ile fungal hastalıklar ve $\%$ 4'ü diğer etmenlerin mücadelesinde tarım ilacını kullandıklarını söylemiş, \% 3'ü ise tarım ilacını hiç kullanmadığ 1 cevabını vermişlerdir.

Siirt Merkez ve ilçelerinde fıstık yetiştiriciliği yapan çiftçilerin en çok karşılaştıkları sorunların başında, önemli verim kayıplarına sebep olan böcekler gelmektedir. Bölgede böceklerden sonra çok yıllık bazı yabancı otlara (tarla sarmaşı̆̆ı, köpek dişi ayrığı, kanyaş vb.) karşı da ilaçlama yapıldığı saptanmıştır. Maddi imkanları iyi olan çiftçilerin yabancı otlar ile mücadele yaptıkları, maddi imkanları yetersiz olan çiftçilerin ise yabancı otlara karşı sadece toprak işleme suretiyle mücadele yaptıkları görülmüştür. Ayrıca bölgede problem haline gelen ve önemli verim kayıplarına sebep olan karazenk hastalığına (Septoria pistaciae Desm.) karşıda ilaçlama yapılmaktadır. Fakat çoğu çiftçimizin bu zararın böceklerden gelen zararla karıştırdıkları ve önemsiz gördükleri gözlemlenmiştir.

Üreticilere "kimyasal savaşımı ne kadar sıklıkla yapıyorsunuz" sorusuna \% 34 'u zararlının yoğunluğuna bakılarak, \% 27'si 15 günde bir, $\%$ 26's1 rastgele, \% 8'i ayda bir ve \% 5'i iki ayda bir cevabını vermişlerdir (Şekil 4). Bu sonuçlara bakıldığında da, çoğu üreticinin kimyasal savaşıma karar vermede zararlının yoğunluğuna bakmayarak zamansız ilaçlama yaptığı görülmektedir.

Şekil 5'e bakıldığında, kimyasal savaşımda çiftçilerin ilaç dozunu seçimini; \% 29'u ilaç ambalajlarının üstündeki etikete göre, \% 28'i ilaç bayisin önerisine göre, \% 20'si tarım teşkilatlarının önerilerine göre, \% 16's1 kendi tecrübelerine ve diğer üreticilerin bilgisine göre ve \% 7'si ise tüm zararlıları yok edecek şekilde yaptıkları saptanmıştır. Daha önce bu konuda yapılan çalışmalarda çiftçilerin daha çok ilaç bayilikleri ile muhatap oldukları bildirmişlerdir (İnan ve Boyraz, 2002, 2003; Kalıpcı ve ark., 2011 ). Literatürdeki bu veriler incelendiğinde, bizim bulgularımızla farklılık gösterse de, üreticilerin çoğunluğunun ilaç dozu ayarlamasında ilacın etiketindeki dozu dikkate almadıkları saptanmıştır.

Çiftçilerin ilaç etiketine uymamalarının farklı nedenleri; a) Çiftçilerin mezuniyet durumlarından dolayı okuma yazmalarının olmaması, b) Çiftçilerin çevrelerindeki üreticilerinden etkilenerek ilaç kutusu kapağının ölçek olarak kullanılması, c) "biz ne kadar çok ilaç dozu kullanırsak o kadar çok hastalık, zararlı, ve yabancı otları daha çok ve daha çabuk yok edebiliriz" gibi yanlış kanı ve

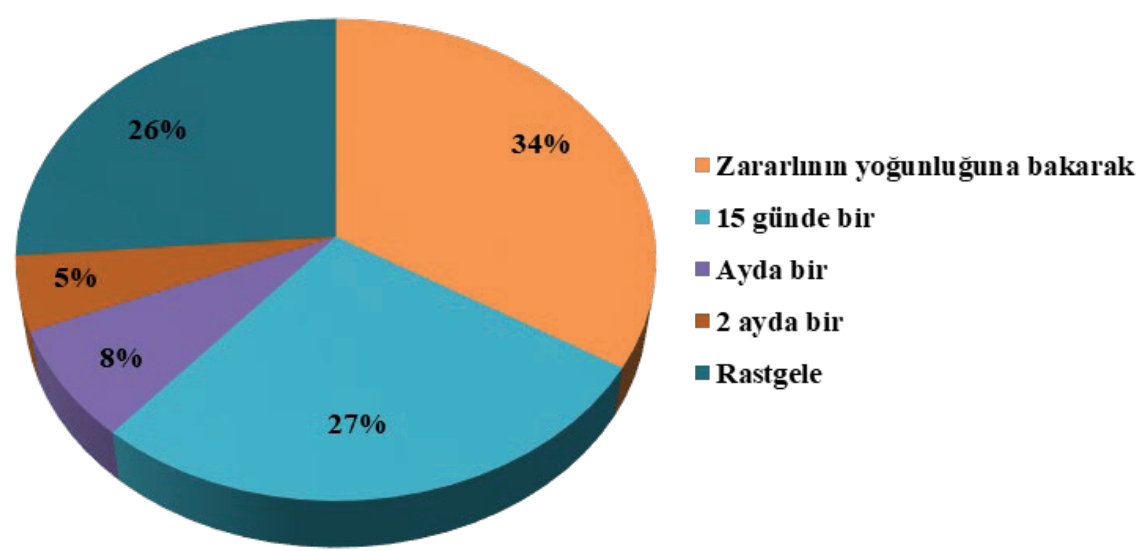

Şekil 4. Bahçe ilaçlaması ne kadar sıklıkla yapıldığg 


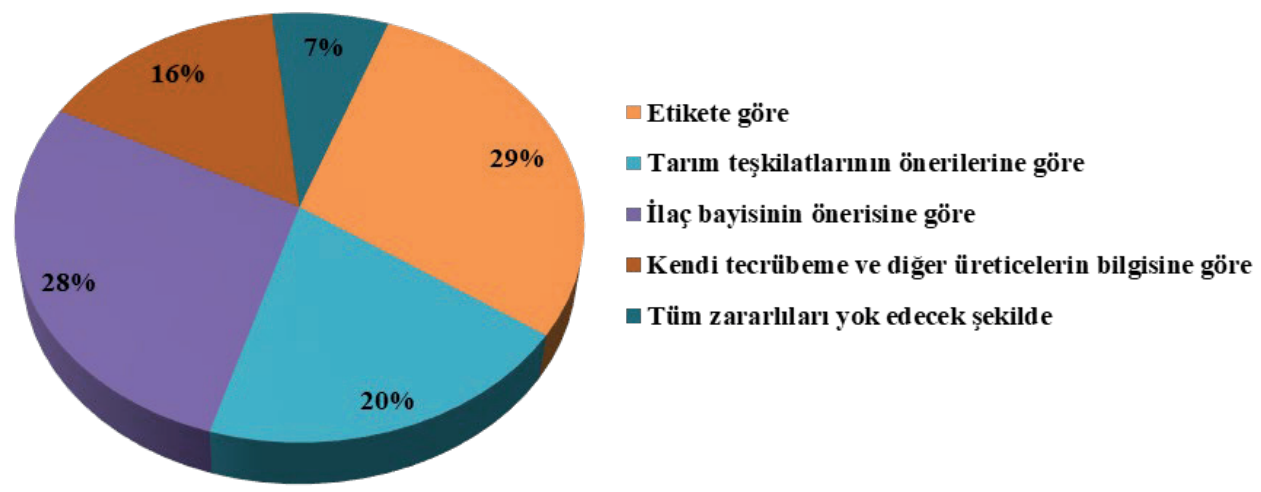

Şekil 5. Tarım ilacı kullanım dozunu belirleme

düşüncesinin üreticilerde hakim olmasıdır. Bu tür sebeplerden dolayı yanlış düşünceler ve davranışların içinde olan bu üreticiler hem üretim maliyetini yükseltilmesine hem de çok daha önemli olan insan sağlığı, çevre ve biyoçeşitliliği esas almayarak doğal dengeyi bozmasına neden olmaktadır. Böylece doğal yaşam da geri dönüşü olmayan büyük yıkıma sürüklenmektedir.

Üreticilerin ilaçlamadan sonra ilaç ambalajlarına uyguladıkları işlemler hususunda; \% 46'sinın yakıyorum, \% 24'ü çöpe atıyorum, \% 19'u toprağa gömüyorum, \% 9'u tarlada bıraktığını ve \% 2'si ise değişik amaçlar için temizleyip tekrar kullandığ 1 şeklinde cevap vermişlerdir. Üreticilerin $\% 65^{\prime}$ i bu konuda bilinçli ve hassas davrandığını, ilaç ambalajlarının imhasını yaptıkları anlaşılmaktadır (Şekil 6). Fakat Türkiye'deki farklı bölgelerde yapılan diğer araştırma sonuçlarında, çiftçilerin boş ilaç kutularını uygun yöntemlerle yok etmeyip çevreye rastgele attıkları bildirilmiştir (İnan ve Boyraz, 2002). Hiçbir işleme tabi tutulmadan boş ilaç kutularının direk çöplüklere atılması da sakıncalı olup hem çevre kirlenmesine hem de çöplüklerde yaşayan birçok canllya zarar verdiği ve zehirlediği unutulmamalıdır. Çevre kirliliğine sebep olacak uygulamaların \% 35 oranında olduğu, Türkiye'de bu konuda yapılan diğer çalışmalara göre Siirt ve ilçelerindeki üreticilerin çevre duyarlılı̆̆ konusundaki bu soruna daha bilinçli ve hassas davrandıkları verdikleri cevaplar ile söylenebilir.

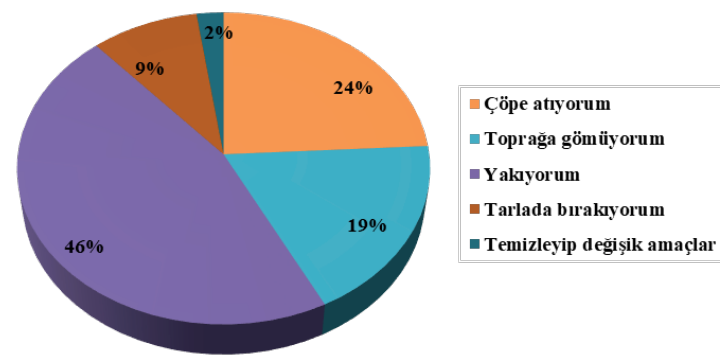

Şekil 6. Çiftçilerin boş ilaç kutularını bertaraf işlemleri
Şekil 7'de verilen üreticilerin tarım ilacı kalıntı sorununa ait görüşlerine bakıldığında; \% 33 oranında "yağmur yıkaması ile kaybolur", \% 39 oranında "kalıntı hakkında bilgim yok", \% 16 oranında "kalıntı bırakır" cevab1 vermelerine rağmen; bu sorunu önemseyen fakat mecbur tarım ilacını kullandıklarını ifade etmişlerdir. Diğer taraftan \% 12 oranında çiftçi ise tarım ilaçlarının kalıntı bırakmadığını söylemişlerdir. Bizim bulgularımıza benzer şekilde İnan ve Boyraz (2002), Konya'da üreticilerin \% 86'sının kullanılan tarım ilaçların kalıntı bırakmayacağını bildirmişlerdir. Peker (2012), Konya ilinde, domates üreticilerinin \% 40'ının ilaç kalıntısının yıkama ile kaybolacağını cevabını verdiklerini bildirmiştir. Erdoğan ve Gökdoğan (2017), Nevşehir ilinde yürüttüğü çalışmada, patates üreticilerinin \% 74.1'i kullanılan tarım ilaçlarının kalıntı bırakmadığg yönünde görüşlerini belirttiklerini bildirmişlerdir.

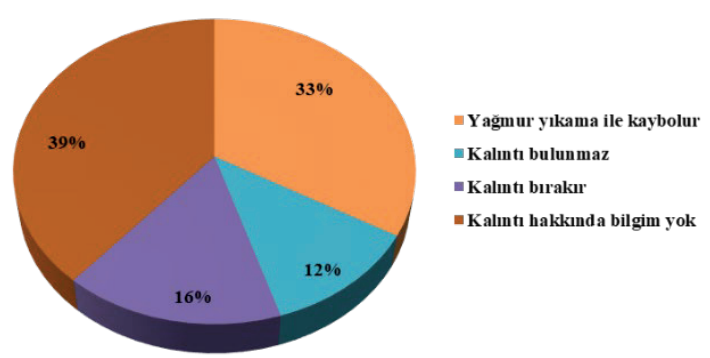

Şekil 7. Tarım ürünlerinde tarım ilacı kalıntılarına ait görüşler

Şekil 8 incelendiğinde, "biyolojik mücadele hakkında bilginiz var mı?" sorusuna, üreticiler; $\% 83$ oranında "hayır", \% 17 oranında "evet" cevabını vermişlerdir. $\mathrm{Bu}$ sonuçlara bakıldığında üreticilerin büyük çoğunluğunun biyoloji mücadele konusunda bilgi sahibi olmadikları ortaya konulmuştur. Aynı şekilde Bayraktar (2018) tarafından, Samsun'da üreticilerin \% 93.8'inin biyolojik mücadele kavramını bilmediği bildirilmiştir. Ancak elde ettiğimiz bulgulardan 
farklı olarak Adana ve Mersin'de yürütülen araştırmada, çiftçilerin \% 60.7'si biyolojik mücadelenin nasıl uygulandığını bildiğini belirtmişlerdir (Temel ve ark., 2017).

Şekil 9 incelendiğinde; üreticilere "Entegre mücadele hakkındaki bilginiz var mı?" sorusu yöneltilmiş, \% 88 oranında "hayır", \% 12 oranında "evet" yanıtı alınmıştır. Bizim çalışmamızda elde edilen bulgulara benzer şekilde Alemdar ve ark. (2019) tarafından Manisa ilinde bağ üreticilerinin entegre mücadele konusunda yeterli bilgi ve tecrübeye sahip olmadıklarını bildirmişlerdir. Ayrıca İzmir ili süs bitkileri yetiştiriciliği yapan üreticilerinin \% 94'ü entegre mücadelenin ne anlama geldiğini bilmedikleri ve tanımadıkları belirlenmiştir (Özercan, 2012). Türkiye'de farklı illerde entegre mücadelenin üreticiler tarafindan bilinirliği bakımından yapılan araştırmada sırasıyla Antalya, Isparta ve Karaman illerinin ön plana çıktığı bildirilmektedir (Gül ve ark., 2014).

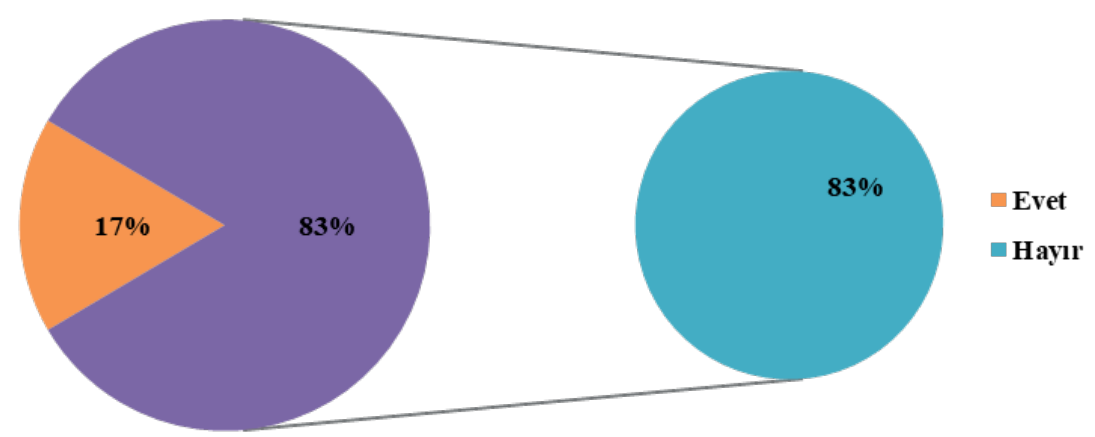

Şekil 8. Üreticilerin biyolojik mücadele hakkında bilgileri

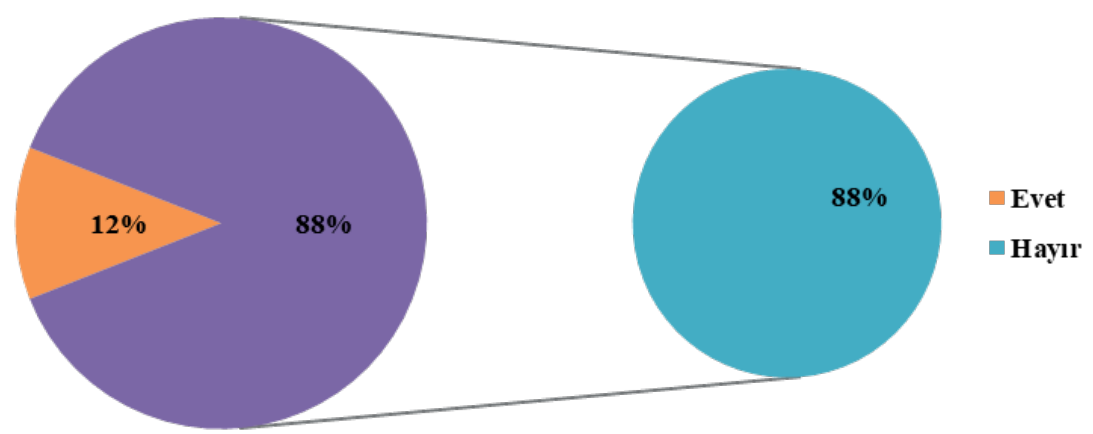

Şekil 9. Üreticilerin Entegre mücadele hakkındaki bilgileri

\section{Sonuçlar}

Tarım ve Orman Bakanlı̆̆ı'nın Antep fistığı teşvik programıyla Antep fistığının bölgedeki dikim alanı gün geçtikçe artmaktadır. Antep fistığı üreticisi için iyi bir ekonomik kaynak olması bölgedeki çiftçiler için vazgeçilmez bir ürün haline gelmiştir. Fakat bölgedeki üreticilerin ağaç başına aldıkları verim, düşük seviyelerde olduğu görülmüştür. $\mathrm{Bu}$ bakımdan tarımsal uygulamaların önemli halkasını oluşturan çiftçilerin birçok konuda bilgi ve sorumlulukları bakımından eksiklerin olduğu araştırma sonunda belirlenmiştir.

Biyolojik mücadele gibi entegre mücadele hakkında da çiftçilerin çoğunun bilgi sahibi olmadıkları görülmüştür. Herhangi bir zararlının popülasyon yoğunluğu eğer ekonomik zarar eşiğinin altında ya da genel denge durumunda ise ilaçlamanın gereksiz olduğu unutulmamalıdır. Aksi takdirde "Entegre mücadele" ilkeleri doğrultusunda yapılmayan bir ilaçlı mücadele, doğadaki tüm canlıları olumsuz etkileyecek; canlıların temel ihtiyaç kaynakları olan su, toprak ve hava kirlenebilecek, besin zincirinde yer alan ve bu kirlenmiş kaynakları kullanan insanlar, hayvanlar ve bitkiler yavaş yavaş sağlıklarını yitirecektir. $\mathrm{Bu}$ sebeple çiftçilere; zararlılara karşı yapacakları kimyasal mücadele yöntemlerinin dışında, çevreci ve daha ekonomik başka mücadele yöntemlerinin olduğu konusunda, gerekli bilgilendirmelerin yapılmasının yerinde olacağı kanısındayız. Aynı zamanda Türkiye'de halihazırda ilaç bayilerinde çalışan elemanların bitki koruma uygulamaları konusunda sahip oldukları bilgilerin üreticileri doğru yönlendirmesi açısından önemlidir.

Dünya Sağl1k Örgütü (World Health Organization, WHO) ve Birleşmiş Milletler Gıda ve 
Tarım Örgütü (Food and Agriculture Organization, FAO) tarafindan oluşturulan "Kodeks Alimentarius Komisyonu" gıda ürünlerinde izin verilen kalıntı tolerans değerlerinin Maksimum Kalıntı Limiti (MRL) değerinin bilinmesi gerekir. Ürüne uygulanan pestisitin MRL üstündeki değerlerinin insan sağlığını olumsuz etkileyeceği kesindir. Dolayısıyla tarımsal ürünlerde oluşan ilaç kalıntısı hakkında çiftçiler eğitilmeli ve bu konuda ilaç analizi yapabilecek laboratuvarlar kurulmalı ve gerekli hizmetler sağlanmalıdır.

Sonuç olarak, tarım ilaçlarına bağlı olarak ortaya çıkabilecek tüm belirtilen bu olumsuzlukların minimum seviyeye indirmek için, Antep fistığ1 yetiştiriciliği yapan bölgedeki üreticilere Tarım ve Orman il ve ilçe müdürlüklerinde çalışan ziraat mühendisleri ya da üniversitelerin Ziraat Fakültelerinde görevli öğretim üyelerinin belirli aralıklar ile koordineli bir biçimde eksik ve bilinçsiz oldukları konularda (Biyolojik ve entegre mücadele, doğal denge, insan ve çevre sağlığı, biyoçeşitlilik ve ekoloji) eğitimler düzenlenmelidir. Önerilen bu hususların yerine getirilmesi ve ilaç uygulamalarının denetlenmesi gerektiği açık bir şekilde görülmektedir.

\section{Kaynaklar}

Aktar, W., Sengupta, D., Chowdhury, A., 2009. Impact of pesticides use in agriculture: their benefits and hazards. Interdisciplinary toxicology, 2(1): 1-12.

Alemdar, Ö., Ataseven, Y., Akkurt, M., 2019. Bağcılıkta iyi tarım uygulamaları hakkında üreticilerin bilgi düzeyinin incelenmesi: Manisa ili, Salihli ilçesi örneği. Çanakkale Onsekizmart Üniversitesi Ziraat Fakültesi Dergisi, 7(1): 151-159.

Anonim, 2015. T.C. Siirt İli 2013-2014 Faaliyet Raporu. Siirt Valiliği, Gıda Tarım ve Hayvancılık İl Müdürlüğü.

Anonim, 2019. Bitkisel Üretim İstatistikleri. Türkiye İstatistik Kurumu (TÜIK), (http://www.tuik.gov.tr/), (Erişim tarihi: 24.12.2019).

Aslıhan, Ö., Özbolat, K., Dığrak, M., 2009. Kahramanmaraş yöresinde yaygın olarak kullanılan bazı pestisitlerin toprak mikroorganizmaları üzerine etkisi. Kahramanmaraş Sütçü İmam Üniversitesi Doğa Bilimleri Dergisi, 12(1): 23-28.

Aydın, M.H., 2019. Siirt ilinde Antepfıstığı (Pistacia vera $\mathrm{L}$.) bahçelerinde hastalıkların tespiti. I. Uluslararası Harran Multidisipliner Çalışmalar Kongresi, 8-10 Mart, Şanlıurfa, Türkiye, s. 85-86.

Bayraktar, A., 2018. Üreticilerin tarımsal mücadele ilaçlarını bilinçli bir şekilde kullanmalarını etkileyen faktörler: Samsun ili. Yüksek lisans tezi, Ondokuz Mayıs Üniversitesi Fen Bilimleri Enstitüsü, Samsun.

Brammall, R.A., Higgins, V.J., 1988. The effect of glyphosate on resistance of tomato to Fusarium crown and root rot disease and on the formation of host structural defensive barriers. Canadian Journal of Botany, 66(8): 1547-1555.

Emeli, M., 2006. Seyhan ve Yüreğir havzasında bitki koruma yöntemlerinin uygulamadaki sorunları üzerine bir araştırma. Yüksek lisans tezi, Çukurova Üniversitesi Fen Bilimleri Enstitüsü, Adana.

Erdoğan, O., Gökdoğan, O., 2017. Nevşehir ilinde patates üreticilerinin bitki koruma uygulamaları. Derim, 34(1): 51-60.

Forget, G., 1993. Balancing the need for pesticides with the risk to human health. In Impact of pesticide use on health in developing countries: proceedings of a symposium held in Ottawa, 17-20 September, Ottawa, Canada, pp. 2-15.

Gül, M., Akpınar, M.G., Demircan, V., Yılmaz, H., Bal, T., Arıcı, Ş.E., Polat, H., Şan, B., Eraslan, F., Örmeci Kart M.Ç., Gürbüz, D., Yılmaz, Ş.G., 2014. Zirai ilaç bayilerinin yapısı ve entegre mücadele konusundaki tutum ve davranışları. Süleyman Demirel Üniversitesi Ziraat Fakültesi Dergisi, 9(2): 11-25.

Igbedioh, S.O., 1991. Effects of agricultural pesticides on humans, animals, and higher plants in developing countries. Archives of Environmental Health: An International Journal, 46(4): 218-224.

İnan, H., Boyraz, N., 2002. Konya çiftçisinin tarım ilacı kullanımının genel olarak değerlendirilmesi. Selçuk Üniversitesi Ziraat Fakültesi Dergisi, 16(30): 88101.

İnan, H., Boyraz, N., 2003. Konya ilindeki zirai ilaç bayilerinin bazı yönlerden değerlendirilmesi. Selçuk Tarım Bilimleri Dergisi, 17(32): 86-96.

Jeyaratnam, J., 1985. Health problems of pesticide usage in the Third World. British Journal of Industrial Medicine, 42(8): 505.

Kalıpcı, E., Özdemir, C., Öztaş, H., 2011. Çiftçilerin pestisit kullanımı ile ilgili eğitim ve bilgi düzeyi ile çevresel duyarlılıklarının araştırılması. TÜBAV Bilim Dergisi, 4(3): 179-187.

Kaplan, C., 2019. Antep fistığı göz kurdu, Thaumetopoea solitaria Frey. üzerinde bazı gözlemler. Uluslararası Tarım ve Kırsal Kalkınma Kongresi, 10-12 Haziran, Siirt, s. 118-123.

Kaplan, C., Çiftçi, M.C., Çakmak, S., 2018. Insect pests in pistachio producing areas of Turkey. Ejons 4. International Congress on Mathematics, Engineering, Natural and Health Sciences, 11-13 August, Kiev, pp. 10-16.

Locke, D., Landivar, J.A., Moseley, D., 1995. The effects of rate and timing on glyphosate applications on defoliation efficiency, regrowth inhibition, lint yield, fiber quality and seed quality. In Beltwide Cotton Conferences, 4-7 January, San Antonio, pp. 10181020.

Mehrnejad, M.R., 2003. The influence of host species on some biological and behavioural aspects of Dibrachys boarmiae (Hymenoptera: Pteromalidae), parasitoid of Kermania pistaciella (Lepidoptera: Tineidae), Biocontrol Science and Technology, 13(2): 219- 229. 
Newbold, P., 1995. Statistics for Business and Economics. Prentice Hall Inc., USA.

Özercan, E., 2012. İzmir ili süs bitkileri yetiştiriciliğinde iyi tarım uygulamaları potansiyelinin değerlendirilmesi. Doktora tezi, Ege Üniversitesi Fen Bilimleri Enstitüsü, İzmir.

Özgen, İ., Tarkan, A., Kaplan, M., 2015. Antepfistığ 1 ağaçlarında zararlı Lepidosaphes pistaciae (Archangelskaya) (Hemiptera: Diaspididae)'nin Siirt ili antepfıstığı bahçelerindeki popülasyon değişimleri ve Cybocephalus fodori Minor (Endrody-Younga) (Coleoptera: Cybocephalidae) ile İlişkileri. Harran Tarım ve Gida Bilimleri Dergisi, 19(2): 75-80.
Peker, A.E., 2012. Konya ili domates üretiminde tarımsal ilaç kullanımına yönelik çevresel duyarlılık analizi. I Igdır Üniversitesi Fen Bilimleri Enstitüsü Dergisi, 2(1): 47-54.

Rad, H.H., 2006. Study on the biology and distribution of long-horned beetles Calchaenesthes pistacivora $\mathrm{n}$. sp. (Col.: Cerambycidae) a new pistachio and wild pistachio pest in Kerman province. Acta Horticulturae, 726: 425-430.

Temel, N., Yarpuzlu, F., Tüfekli, M., Karut, Ş.T., Portakaldal1, M., Seçer, A., 2017. Sürdürülebilir tarımda biyolojik mücadelenin yeri konusunda çiftçilerin bilgi düzeyinin belirlenmesi. Türkiye Biyolojik Mücadele Dergisi, 8(1): 71-82. 